\title{
In vitro Transcription and Translation Directed by Caulobacter crescentus CB 15 Nucleoids
}

\author{
By UTHAYA K. SWOBODA, CRAWFORD S. DOW* AND \\ LJUBISA VITKOVIC $†$ \\ Department of Biological Sciences, University of Warwick, Coventry CV4 7AL, U.K.
}

(Received 10 March 1981)

\begin{abstract}
Envelope-associated nucleoids isolated from Caulobacter crescentus contained DNAdependent RNA polymerase and nascent RNA. In the presence of nucleotide substrates, and under suitable conditions, RNA chain elongation took place at similar rates on both fast sedimenting (FS) and slow sedimenting (SS) nucleoids. Reinitiation of transcription did not occur in vitro except when exogenous holoenzyme was added to the assay system. Three major classes of RNA were synthesized in vitro. The two larger species were heterodisperse and had electrophoretic mobilities equivalent to 16-20S and 23-35S. The third class contained RNA in the region of 3-4S. The high molecular weight components were absent from RNA synthesized on FS nucleoid templates whereas the 3-4S fraction was much increased.

Caulobacter crescentus nucleoids were also examined for the presence of mRNA in a protein-synthesizing system derived from Escherichia coli cells. The activity of heterologous mRNA was detectable only after the conversion of $E$. coli cell lysates into an mRNA-dependent translation system by treatment with micrococcal nuclease. Incorporation of $\left[{ }^{35} \mathrm{~S}\right]$ methionine into trichloroacetic acid-insoluble material reflected synthesis of bona fide template-specific polypeptides by several criteria showing that SS and FS envelope-associated nucleoids contained biologically active mRNAs. Since the nucleoids were transcriptionally inactive during protein synthesis, the assay reflected the presence of mRNAs produced at different stages in the Caulobacter cell cycle. The translational capacity of the nucleoids increased markedly after transcription indicating that some RNA synthesized in vitro was mRNA. The specific activity of transcribed nucleoids as templates for protein synthesis supported the contention that the predominant RNAs synthesized in vitro were rRNAs and their precursors.
\end{abstract}

\section{INTRODUCTION}

Morphogenesis and differentiation in prokaryotes must involve control systems which regulate the timing of each cell cycle event and coordinate them to produce structural and metabolic changes in the differentiating cells. The study of the control of transcription and translation requires a suitable in vitro system in which the control systems, as they exist in the living cell, have not been greatly perturbed or disorganized. At present, bacterial nucleoids provide the best available model system for this purpose and have been studied in detail in Escherichia coli (Giorno et al., 1975; Pettijohn, 1976) and Bacillus subtilis (Guillen et al., 1977; Hirschbein et al., 1976).

In previous papers we described the isolation of two types of nucleoids from heterogeneous populations of exponentially growing Caulobacter crescentus CB 15 cells (Swoboda \& Dow,

† Present address: Microbiology Research Group, Department of Pharmacy, University of Aston, Birmingham B4 7ET, U.K. 
1979; Swoboda et al., 1982). Fast sedimenting (FS) and slow sedimenting (SS) envelope-associated nucleoids were separated by density gradient centrifugation and characterized, with respect to the cell types from which they were derived, by cell envelope morphology. It was hypothesized that the SS nucleoids were derived from cells undergoing DNA replication while FS nucleoids were derived from cells (predominantly swarmer cells) in which there was no DNA synthesis. This was not, however, thought to be the major reason for the difference in sedimentation coefficients (5600S and 7100S); the difference was thought to be due to the enhanced protein to DNA ratio of the FS nucleoids. In this paper we report in vitro transcription and translation studies using both types of nucleoids.

\section{METHODS}

Chemicals. Trizma base, nucleoside triphosphates, rifampicin, E. coli RNA polymerase [specific activity 900 units (mg protein $)^{-1}$, pancreatic ribonuclease $A$ and bovine serum albumin were purchased from Sigma. Deoxyribonuclease I (RNAase-free) was obtained from Worthington. Micrococcal nuclease and phosphoenolpyruvate were purchased from Boehringer. $\left[5^{3}{ }^{3} \mathrm{H}\right]$ Uridine $5^{\prime}$-triphosphate $\left(15 \mathrm{Ci} \mathrm{mmol}^{-1}, 0.56 \mathrm{TBq} \mathrm{mmol}^{-1}\right)$, $\left.\mathrm{L}-{ }^{33} \mathrm{~S}\right]$ methionine $\left(600 \mathrm{Ci} \mathrm{mmol}^{-1}, 22 \mathrm{TBq} \mathrm{mmol}^{-1}\right)$, adenosine $5^{\prime}-\left[\gamma^{32} \mathrm{P}\right]$ triphosphate $\left(3000 \mathrm{Ci} \mathrm{mmol}^{-1}, 111 \mathrm{TBq}\right.$ $\left.\mathrm{mmol}^{-1}\right)$ and uridine $5^{\prime}-\left[\alpha_{-}^{-32} \mathrm{P}\right]$ triphosphate $\left(400 \mathrm{Ci} \mathrm{mmol}^{-1}, 14.8 \mathrm{TBq} \mathrm{mmol}^{-1}\right)$ were obtained from Amersham. All other chemicals were purchased from BDH, unless otherwise stated.

Bacterial strains and growth conditions. Caulobacter crescentus $\mathrm{CB} 15$ was grown at $30^{\circ} \mathrm{C}$ in Hunter's minimal medium (Swoboda et al., 1982). Escherichia coli strains MRE600 and B were grown at $37^{\circ} \mathrm{C}$ in YK medium (Hagen \& Young, 1973). Bacillus licheniformis A5 was grown at $37^{\circ} \mathrm{C}$ in B medium (Vitkovic \& Sadoff, 1977).

Preparation of templates. Fast sedimenting (FS) and slow sedimenting (SS) envelope-associated nucleoids were isolated from heterogeneous populations of exponentially growing $C$. crescentus cells as described by Swoboda $e t$ al. (1982). Nucleoids were used in transcription and translation experiments immediately after isolation. RNA synthesized in vitro was translated without purification immediately after transcription. RNA standards were prepared as described by Swoboda et al. (1982), but E. coli and B. licheniformis RNA for translation studies was extracted from exponentially growing cells as described by Hagen \& Young (1973).

\section{In vitro transcription studies}

(i) In vitro RNA synthesis. Reaction mixtures contained the following constituents in a final volume of $0.2 \mathrm{ml}$ : $1 \mathrm{mM}$ each of ATP, CTP, GTP; $0.05 \mathrm{mM}-\mathrm{UTP} ; 1 \mu \mathrm{Ci}\left[{ }^{3} \mathrm{H}\right] \mathrm{UTP} \mathrm{ml}^{-1}$, or $1 \mu \mathrm{Ci}\left[{ }^{32} \mathrm{P}\right] \mathrm{ATP} \mathrm{ml} \mathrm{m}^{-1} ; 12.5 \mathrm{mM}-\mathrm{MgCl}_{2}$; $100 \mathrm{~mm}$-Tris $/ \mathrm{HCl}\left(\mathrm{pH} 7.5\right.$ at $\left.20^{\circ} \mathrm{C}\right) ; 7.5 \mathrm{mM}-2$-mercaptoethanol; $1 \mathrm{~mm}$-spermidine hydrochloride; specified concentrations of nucleoids; $5 \mu \mathrm{g}$ of $E$. coli DNA-dependent RNA polymerase holoenzyme. Reactions were started by transferring the assay mixtures from $0{ }^{\circ} \mathrm{C}$ to $37^{\circ} \mathrm{C}$. Duplicate $20 \mu \mathrm{l}$ samples were removed at regular intervals, spotted on to Whatman $3 \mathrm{MM}$ filter discs, immersed immediately into ice-cold $5 \%(\mathrm{w} / \mathrm{v})$ trichloroacetic acid (TCA) containing $0.1 \%(\mathrm{w} / \mathrm{v})$ tetra-sodium pyrophosphate and left for $10 \mathrm{~min}$. Filters were washed twice in the $5 \% \mathrm{TCA} / 0.1 \%$ tetra-sodium pyrophosphate solution and twice in ethanol at $10 \mathrm{~min}$ intervals before being dried and counted in $3 \mathrm{ml}$ of Triton/toluene scintillant in a Packard Tri-Carb liquid scintillation spectrometer.

(ii) Purification of transcripts from the reaction mixture. Protein and labelled triphosphates were removed from the RNA by phenol extraction (Kirby, 1965). The transcription assay mixture was scaled up to $2 \mathrm{ml}$. At $5 \mathrm{~min}$ and $40 \mathrm{~min}$ after the initiation of RNA synthesis, $1 \mathrm{ml}$ of the mixture was diluted to $2 \mathrm{ml}$ with water and added to $2 \mathrm{ml}$ of double-strength Kirby mixture $[50 \mathrm{mM}-\mathrm{KCl}, 1 \%(\mathrm{w} / \mathrm{v})$ tri-isopropyl naphthalenesulphonate, $6 \%(\mathrm{w} / \mathrm{v})$ 4-aminosalicylic acid (sodium salt), $10 \mathrm{~mm}$-Tris $/ \mathrm{HCl}, \mathrm{pH} \mathrm{7.6]}$. Total nucleic acid was extracted with $8 \mathrm{ml}$ of a phenol $/ m$-cresol/8-hydroxyquinoline mixture $(500: 70: 0.5$, by wt). After shaking for $2 \mathrm{~min}$ the phases were separated by centrifugation at $3500 \mathrm{~g}$ for $10 \mathrm{~min}$. The nucleic acid was re-extracted from the aqueous phase two or three times more and precipitated overnight with 2 vol. ethanol after the addition of $100 \mu \mathrm{g}$ of $E$. coli RNA to act as carrier during the alcohol precipitation. The nucleic acid was recovered by centrifugation $\left(3500 \mathrm{~g}\right.$ at $4{ }^{\circ} \mathrm{C}$ for $15 \mathrm{~min}$ ) and washed twice in a solution containing $70 \%(\mathrm{v} / \mathrm{v})$ ethanol, $0.5 \%(\mathrm{w} / \mathrm{v})$ sodium dodecyl sulphate (SDS) and $0 \cdot 1 \mathrm{M}-\mathrm{NaCl}$, before checking the purity by scanning with a Pye Unicam SP800 spectrophotometer. Washing was repeated until there was no contamination by either phenol or carbohydrate. The resulting total nucleic acid was washed twice in $70 \%$ ethanol to remove the SDS. DNA was then removed by treating with $100 \mu \mathrm{g}$ DNAase I (RNAase-free) at room temperature for $30 \mathrm{~min}$, and the RNA was re-extracted with the phenol mixture. RNA was precipitated with $2 \mathrm{vol}$. ethanol at $-20^{\circ} \mathrm{C}$ overnight, recovered by centrifugation, washed twice with a solution containing $70 \%$ ethanol, $0.1 \%$ SDS and $0.1 \mathrm{M}-\mathrm{NaCl}$, resuspended in $0.1 \mathrm{M}$-sodium acetate buffer, pH 6.2 , containing $0.5 \%$ SDS, and reprecipitated with 2 vol. ethanol. RNA was stored in 2 vol. ethanol at $-20^{\circ} \mathrm{C}$ until required. As a control, during DNAase treatment, duplicate samples to the above were treated with $100 \mu \mathrm{g}$ RNAase A. 
To determine the level of incorporation of ${ }^{3} \mathrm{H}$ or ${ }^{32} \mathrm{P}$ into the RNA, $10 \mu \mathrm{l}$ of a solution of known concentration of labelled RNA dissolved in the SDS/sodium acetate buffer, $\mathrm{pH} 6.2$, was spotted on to a Whatman GF/A glass-fibre disc, washed, dried and the radioactive content was determined.

(iii) Polyacrylamide gel electrophoresis of transcripts. The size of the ${ }^{3} \mathrm{H}$-labelled RNA synthesized in vitro was determined by electrophoresis on $2.4 \%$ (w/v) polyacrylamide gels, as described by Loening $(1967,1969)$. In view of the quenching of ${ }^{3} \mathrm{H}$ counts by dried polyacrylamide gel slices, a bisacrylamide cross-linked gel, which can be dissolved in hydrogen peroxide, was used. Electrophoresis was at room temperature at a constant current of $5 \mathrm{~mA}$ per gel. After electrophoresis, the gels were transferred to a rectangular quartz cell and scanned using a Gilford spectrometer. At the end of the scan, the length of the gel in the cell was measured and the gel was frozen in an aluminium trough on powdered dry ice. After freezing, each gel was sequentially sliced into $1 \mathrm{~mm}$ slices. The slices were dissolved in $0.3 \mathrm{ml} 30 \%$ hydrogen peroxide by incubating at $60^{\circ} \mathrm{C}$ in sealed scintillation vials overnight. After cooling, $3 \mathrm{ml}$ of Triton/toluene scintillant was added to each vial. The amount of ${ }^{3} \mathrm{H}$ in each gel slice was determined and the RNA profile obtained was related to the ultraviolet scan.

\section{In vitro translation studies}

(i) Preparation of cell-free extract. An S30 extract was prepared from E. coli MRE600 cells as described by Hagen \& Young (1973). In preliminary experiments the extract was preincubated for 20 min at $37^{\circ} \mathrm{C}$ in the presence of $4 \mu \mathrm{g}$ DNAase I $\mathrm{ml}^{-1}$. This failed to lower the incorporation of $\left[{ }^{35} \mathrm{~S}\right]$ methionine into TCA-insoluble material sufficiently. Subsequently, we employed the method of Pelham \& Jackson (1976). DNAase was replaced by $10 \mu \mathrm{g}$ micrococcal nuclease $\mathrm{ml}^{-1}$ in the presence of $1 \mathrm{mM}^{-\mathrm{CaCl}_{2}}$. The digestion of DNA and RNA was terminated by the addition of EGTA to $2 \mathrm{mM}$ final concentration. The S30 extract was then used for protein synthesis.

(ii) Cell-free protein synthesis. The reaction mixture for protein synthesis (usually $100 \mu \mathrm{l}$ ) contained 0.2 mM-GTP, 3.0 mM-ATP, $5.0 \mathrm{~mm}$-phosphoenolpyruvate, $2.4 \mathrm{~mm}$-dithiothreitol (Cleland's reagent), $60 \mathrm{~mm}$ Tris/ $\mathrm{HCl}, \mathrm{pH} 7.8,8.0 \mathrm{~mm}$-magnesium acetate, $110 \mathrm{~mm}$-ammonium acetate, $0.8 \mathrm{~mm}$-2-mercaptoethanol (from the $\mathrm{S} 30$ extract), $0.5 \mu \mathrm{M}$-leucine, $0.05 \mathrm{~mm}$-tyrosine, $0.11 \mathrm{~mm}$ of the other 17 amino acids, $3.8 \mathrm{~mm}$-polyethylene glycol, $5 \mathrm{mg} \mathrm{S30}$ protein $\mathrm{ml}^{-1}$, RNA template and $\left[{ }^{35} \mathrm{~S}\right]$ methionine as indicated.

(iii) Estimation of $\left[{ }^{35} \mathrm{~S}\right]$ methionine incorporation. Bovine serum albumin was added to samples to achieve a final concentration of $2.5 \mathrm{mg} \mathrm{m}^{-1}$ and proteins were precipitated with $1 \mathrm{ml} 10 \%$ TCA for $10 \mathrm{~min}$ at $4{ }^{\circ} \mathrm{C}$. Precipitated material was recovered by centrifuging, resuspended in $0.5 \mathrm{ml} 0.2 \mathrm{M}-\mathrm{NaOH}$, incubated for $15 \mathrm{~min}$ at $45^{\circ} \mathrm{C}$ and reprecipitated with $1.5 \mathrm{ml} 10 \%$ TCA. The precipitate was recovered by filtration through Whatman GF/C glass-fibre discs, washed with $15 \mathrm{ml} 5 \%(\mathrm{w} / \mathrm{v})$ cold TCA and $5 \mathrm{ml} 90 \%$ ethanol and dried. Counting was performed in a toluene-based scintillant by liquid scintillation spectrophotometry. Efficiency of counting was approximately $70 \%$ for $\left[{ }^{35} \mathrm{~S}\right]$ methionine.

(iv) Preparation and electrophoresis of translation products. The reaction products of cell-free protein synthesis were processed essentially as described by Hopper et al. (1975). To $0.8 \mathrm{ml}$ of each sample, $1.0 \mathrm{ml} 90 \%(\mathrm{v} / \mathrm{v})$ aqueous acetone was added to precipitate labelled proteins. Samples were mixed and incubated at $4{ }^{\circ} \mathrm{C}$ for $30 \mathrm{~min}$. The precipitate was pelleted by centrifugation at $4{ }^{\circ} \mathrm{C}$. The supernatant was discarded and residual acetone was removed by evaporation. Cracking buffer $(0.8 \mathrm{ml}$; Studier, 1973) was added, the samples were boiled for $3 \mathrm{~min}$ and then stored at $-20^{\circ} \mathrm{C}$. SDS-polyacrylamide slab gel electrophoresis (SDS-PAGE) was performed as described by Studier (1973) and Lagenaur \& Agabian (1976).

\section{RESULTS}

\section{In vitro transcription studies using nucleoids as templates}

Template capacity of the fast sedimenting and slow sedimenting envelope-associated nucleoids. The reaction mixture for assay of RNA synthesis contained nucleoids, DNA-dependent RNA polymerase, buffer, monovalent and divalent cations and nucleoside triphosphates in the optimal concentrations to give the maximum level of transcription. Spermidine was added to stimulate RNA synthesis in vitro and prevent first order inhibition of RNA polymerase (Loening, 1967; Fuchs et al., 1967). Spermidine also stabilizes the condensed state of the isolated nucleoids increasing their transcriptional capacity in vitro (Flink \& Pettijohn, 1975; Giorno et al., 1975). 2-Mercaptoethanol was added to maintain the DNA-dependent RNA polymerase in a stable, reduced form. RNA synthesis, expressed as the incorporation of $\left[{ }^{3} \mathrm{H}\right] \mathrm{UMP}$ into TCA-precipitable material, as a function of time is shown in Fig. 1. When nucleoids were incubated in the reaction mixture containing all of the substrates except exogenous DNA-dependent RNA polymerase, some RNA synthesis was 


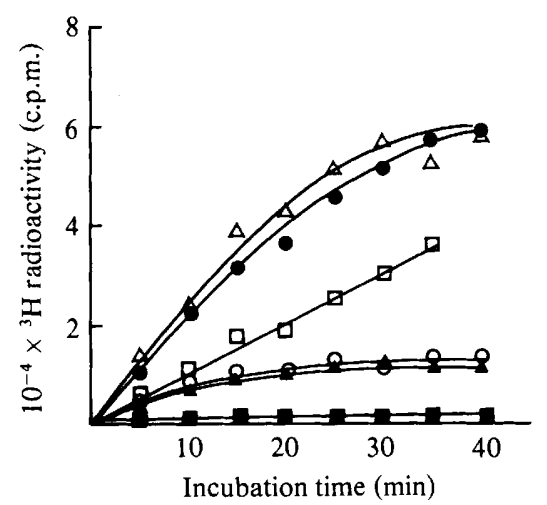

Fig. 1. In vitro RNA synthesis. The kinetics of incorporation of $\left[{ }^{3} \mathrm{H}\right] \mathrm{UTP}$ by $10 \mu \mathrm{g}$ of SS or FS envelope-associated nucleoids or calf thymus DNA, with and without the addition of $E$. coli RNA polymerase, was determined as described in Methods. Samples $(20 \mu \mathrm{l})$ were removed at intervals and the ${ }^{3} \mathrm{H}$ incorporated into RNA was determined. SS nucleoids (A); SS nucleoids plus $E$. coli RNA polymerase $(\triangle)$; FS nucleoids $(O)$; FS nucleoids plus $E$. coli RNA polymerase $(O)$; Calf thymus DNA (匹); Calf thymus DNA plus $E$. coli RNA polymerase ( $\square$ ).

Table 1. Characterization of incorporation of $\left[{ }^{3} H \mid U T P\right.$ by SS envelope-associated nucleoids of $C$. crescentus

\begin{abstract}
Assays for incorporation (40 min incubation) were performed according to the procedure in Methods. Where indicated, rifampicin was added at $200 \mu \mathrm{g} \mathrm{ml}^{-1}$, actinomycin D at $50 \mu \mathrm{g} \mathrm{ml}^{-1}$ and RNAase I at $\mathrm{l} \mu \mathrm{g} \mathrm{ml} \mathrm{I}^{-1}$.
\end{abstract}

$\begin{array}{lc}\text { Constituents } & \begin{array}{c}\text { Relative } \\ \text { incorporation }\end{array} \\ \text { Standard assay mixture } & (\%) \\ \text { + Rifampicin } & 100 \\ \text { + Actinomycin D } & 20 \\ \text { - RNA polymerase } & 19 \\ \text { - RNA polymerase + rifampicin } & 21 \\ \text { - RNA polymerase + rifampicin after 5 min } & 21 \\ \text { - ATP, GTP or CTP } & 21 \\ \text { - ATP, GTP and CTP } & 10 \\ \text { + RNAase } & <1 \\ \end{array}$

detected, indicating that both the FS and SS envelope-associated nucleoids contained active endogenous DNA-dependent RNA polymerase. When exogenous $E$. coli RNA polymerase was added to the reaction mixture, with DNA as the limiting factor, the rate of RNA synthesis increased 3- to 4-fold. Within experimental error, the rates of RNA synthesis by equal concentrations of FS and SS envelope-associated nucleoids were almost identical. Synthesis was initiated immediately at the incubation temperature and continued for over 60 min. The rate of synthesis remained linear and constant for $30 \mathrm{~min}$. Three control experiments confirmed that the measurements represented in vitro RNA synthesis (Table 1): (i) the omission of either ATP or CTP or GTP reduced incorporation by $90 \%$; (ii) no TCA-insoluble radioactive material was recovered after treatment with pancreatic RNAase A; (iii) addition of actinomycin D or rifampicin (see also Fig. 3) reduced incorporation by $80 \%$.

The sedimentation coefficients of the FS and SS nucleoids showed no appreciable change during the time course of the transcription experiments. 




Fig. 2. Effect of salt concentration on transcription. Assays were performed by the standard procedure described in Methods except that the $\mathrm{NaCl}$ concentration was varied as indicated. SS envelopeassociated nucleoids ( $\square$ ); FS envelope-associated nucleoids $(\boldsymbol{\Delta})$; calf thymus DNA $(\boldsymbol{O})$.



Fig. 3. Effect of rifampicin on RNA synthesis by FS and SS envelope-associated nucleoids in the presence and absence of $E$. coli RNA polymerase. Rifampicin was added to $10 \mu$ assay mixtures to give $200 \mu \mathrm{g} \mathrm{ml}^{-1}$. $(a, c)$ Transcription of FS $(a)$ and SS $(c)$ nucleoids in the presence of $E$. coli RNA polymerase without rifampicin (O) and with rifampicin $(O) .(b, d)$ Transcription of FS $(b)$ and SS $(d)$ nucleoids by endogenous RNA polymerase without rifampicin $(\triangle)$ and with rifampicin added at zero time ( $\square$ ) and after 5 min incubation ( $\square$ ).

In the presence of exogenous $E$. coli DNA-dependent RNA polymerase both FS and SS envelope-associated nucleoids were more efficient templates than purified calf thymus DNA (Fig. 1).

Effect of salt and temperature on transcription. High ionic conditions were not conducive to maximal RNA synthesis. When both FS and SS envelope-associated nucleoids were incubated with increasing concentrations of $\mathrm{NaCl}$ in the assay mixture, the rate of RNA synthesis decreased until at $200 \mathrm{~mm}-\mathrm{NaCl}$ no synthesis occurred. Maximal synthesis was obtained when the salt concentration was $10 \mathrm{~mm}$ (Fig. 2). Transcription of calf thymus DNA 


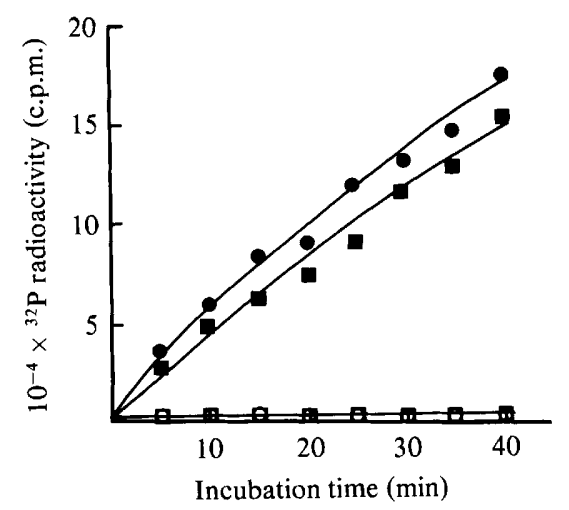

Fig. 4. Kinetics of incorporation of $\left[\gamma^{-32} \mathrm{P}\right] \mathrm{ATP}$ and $\left[\alpha^{-{ }^{32}} \mathrm{P}\right] \mathrm{UTP}$ into RNA synthesized from FS and SS envelope-associated nucleoids. Assays were performed as described in Methods in the presence of $\left[\alpha_{-}{ }^{32} \mathrm{P}\right]$ UTP or $\left[\gamma_{-}{ }^{32} \mathrm{P}\right]$ ATP $\left.(1 \mu \mathrm{Ci} \mathrm{m}]^{-1}\right)$. Incorporation from $\left[\alpha^{-32} \mathrm{P}\right]$ UTP by FS $(\square)$ and SS (O) nucleoids; incorporation from $\left[\gamma^{32} \mathrm{P}\right]$ ATP by FS $(\square)$ and SS $(O)$ nucleoids.

was affected differently by the salt concentration (Fig. 2). For both nucleoids and calf thymus DNA, in vitro RNA synthesis was maximal at $37^{\circ} \mathrm{C}$.

Nature of RNA synthesis in vitro. Transcription by exogenous polymerase of both FS and SS envelope-associated nucleoids was rifampicin-sensitive but the antibiotic had no effect on endogenous RNA synthesis (Fig. 3). In the presence of rifampicin, the concentration of RNA synthesized by exogenous DNA-dependent RNA polymerase dropped to the endogenous level. Since rifampicin is an inhibitor of chain initiation but not chain growth, these results suggested that reinitiation of transcription by endogenous RNA polymerase did not occur in either the FS or SS envelope-associated nucleoids, but did occur once exogenous RNA polymerase had been added.

Reinitiation of RNA chains was also followed by measuring the incorporation of $\left[\gamma^{-32} \mathrm{P}\right]$ ATP into TCA-insoluble RNA. The level of incorporation was very low (40 min incubation time) when compared with $\left[\alpha^{-32}\right.$ P UTP incorporation in the control experiment (Fig. 4).

Analysis of RNA synthesized in vitro. The RNA products synthesized on the isolated nucleoids by incubation for $5 \mathrm{~min}$ and $40 \mathrm{~min}$ were purified and analysed by polyacrylamide gel electrophoresis. (From data on the kinetics of RNA synthesis, 40 min was sufficient time to complete chain elongation.) Polyacrylamide disc gels (Fig. 5) indicated that both FS and SS envelope-associated nucleoids synthesized homogeneous low molecular weight transcripts. In addition, the SS envelope-associated nucleoids synthesized two larger molecular weight species which appeared as heterogeneous peaks. Traces of these were also apparent during transcription of FS nucleoids. Comparison of the in vitro transcripts with $E$. coli marker RNAs indicated that the transcripts with the greatest electrophoretic mobility, which were synthesized by both FS and SS envelope-associated nucleoids, had a sedimentation coefficient of $3.2 \mathrm{~S}( \pm 0.5 \mathrm{~S})$. The larger of the two high molecular weight species had a sedimentation coefficient ranging from approximately $23 \mathrm{~S}$ to $35 \mathrm{~S}$, while the smaller component had a sedimentation coefficient ranging from $16 \mathrm{~S}$ to $20 \mathrm{~S}( \pm 0.5 \mathrm{~S})$ (Pettijohn et al., 1970a,b). The heterogeneity of these two peaks could be explained by assuming that the larger species, besides containing mature 23S rRNA, also contained the precursor molecules of $30 \mathrm{~S}$ and $25 \mathrm{~S}$ RNA, while the smaller species contained not only the 16S rRNA but also the $17.5 \mathrm{~S}$ precursor. In prokaryotes, the $30 \mathrm{~S}$ precursor is rapidly cleaved during the course of its synthesis to $25 \mathrm{~S}$ and $17.5 \mathrm{~S}$ RNA fragments, which in turn are further processed to the mature 23S and 16S rRNA (Nikolev et al., 1973, 1974). The presence of the 3-4S RNA may be 

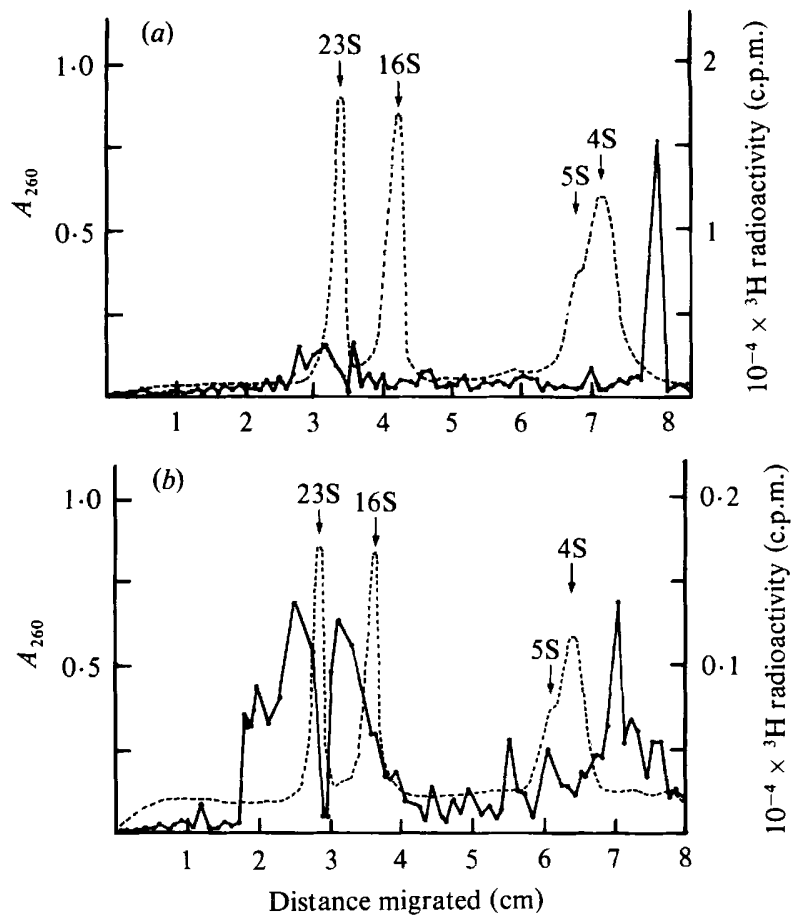

Fig. 5. Polyacrylamide gel electrophoresis of RNA synthesized in vitro. Transcription (40 min), purification and sizing of transcripts was carried out as described in Methods. Unlabelled marker RNAs were extracted by the method of Kirby (1965). Electrophoresis was carried out in $2.4 \%$ polyacrylamide gels at $5 \mathrm{~mA}$ per gel and at a constant voltage for 3-4 h. Radioactivity in transcripts synthesized on FS (a) and SS (b) envelope-associated nucleoids (-); $A_{260}$ of $E$. coli rRNA and tRNA (---).

explained as being due to insufficient polymerization or frequent chain termination, to degradation of RNA, to the release of the 'spacer' regions, by endonucleolytic degradation, from the ribosomal precursor RNA molecules, or to tRNA. The high background and the incomplete resolution of the peaks could be due, at least in part, to the synthesis of mRNA on the nucleoids.

\section{Nücleoid-directed cell-free protein synthesis}

Modification of S30 extract. An S30 extract prepared from E. coli is saturated with endogenous mRNA and is capable of in vitro transcription of endogenous DNA (Zubay, 1973). Additional mRNA will, therefore, only be translated to the extent that it competes with the endogenous mRNA. In order to measure the stimulation by exogenously added mRNA, and to detect the products synthesized, the S30 extract was preincubated in the presence of DNAase and the absence of labelled amino acid. The aim was to run off endogenous mRNA from the existing polyribosomes and to degrade any endogenous mRNA and DNA present. However, this procedure proved to be insufficient to lower the activity of endogenous mRNA and allow the detection of nucleoid activity. Table 2 shows that the incorporation directed by endogenous mRNA ('background') was much lower after treatment with micrococcal nuclease than with DNAase. Thus, preincubation of the $\mathrm{S} 30$ extract with $\mathrm{Ca}^{2+}$-dependent micrococcal nuclease permitted detection of amino acid incorporation directed by $E$. coli $\mathrm{B}$ and $C$. crescentus mRNA. Similar results have been obtained with coliphage MS2 and $B$. licheniformis A5 mRNA. Background incorporation was reduced 5 -fold by the nuclease compared with DNAase treatment and consequently stimulation by the SS nucleoids increased from 1.1- to 3.8-fold (Table 2). 
Table 2. Effect of preincubation of E. coli $S 30$ extract on amino acid incorporation into TCA-insoluble polypeptides

The techniques used in preincubating S30 extract with DNAase or micrococcal nuclease are described in Methods. Reaction mixtures $(100 \mu \mathrm{l})$ contained preincubated $\mathrm{S} 30$ extract alone or with $E$. coli B exogenous RNA $(0.5 \mu \mathrm{g})$ or $C$. crescentus SS nucleoids (containing $0.5 \mu \mathrm{g} \mathrm{RNA}$ ), and [ $\left.{ }^{35} \mathrm{~S}\right]$ methionine (specific activity $100 \mathrm{Ci} \mathrm{mmol}^{-1}$, final concentration $100 \mathrm{pmol} \mathrm{ml}^{-1}$ ). The mixtures were incubated at $37^{\circ} \mathrm{C}$ for $20 \mathrm{~min}$, and the incorporation of $\left[{ }^{35} \mathrm{~S}\right]$ methionine into TCA-insoluble polypeptides was measured as pmol per $\mathrm{ml}$ reaction mixture.

$\begin{array}{ccccc}\text { Template } & \overbrace{\begin{array}{c}\text { Incorporation } \\ \left.(\mathrm{pmol} \mathrm{ml})^{-1}\right)\end{array}}^{\text {Preincubation with DNAase }} & \begin{array}{c}\text { Stimulation } \\ (- \text { fold })\end{array} & \overbrace{\begin{array}{c}\text { Incorporation } \\ \left(\mathrm{pmol} \mathrm{m}^{-1}\right)\end{array}}^{\text {Preincubation with nuclease }} & \begin{array}{c}\text { Stimulation } \\ (- \text { fold })\end{array} \\ \text { Residual endogenous RNA } & 0.32 & - & 0.07 & - \\ \text { in } \text { E. coli } \text { S30 extract } & 0.71 & 2.2 & 0.35 & 5.0 \\ + \text { E. coli } \text { exogenous RNA } & 0.35 & 1.1 & 0.27 & 3.8\end{array}$

Table 3. Effect of preincubation of C. crescentus nucleoids in a transcription assay mixture on in vitro translation

\begin{abstract}
Reaction mixtures $(100 \mu \mathrm{l})$ were incubated at $37^{\circ} \mathrm{C}$ for $20 \mathrm{~min}$ after addition of $\left[{ }^{35} \mathrm{~S} /\right.$ methionine (specific activity $1205 \mathrm{Ci} \mathrm{mmol}{ }^{-1}$, final concentration $6 \mathrm{pmol} \mathrm{ml}^{-1}$ ). Where indicated, isolated nucleoids were preincubated in an in vitro transcription assay mixture for $40 \mathrm{~min}$. Isolated FS and SS nucleoids contain about the same amount of RNA, i.e. $25-27 \%(w / w)$ of the total cellular DNA (Swoboda et al., 1982), and so the results in the table are directly comparable.
\end{abstract}

\begin{tabular}{|c|c|c|}
\hline \multirow[b]{2}{*}{ Template } & \multicolumn{2}{|c|}{$\begin{array}{c}{\left[{ }^{35} \mathrm{~S}\right] \text { Methionine incorporated in } 20 \mathrm{mi}} \\
{\left[\mathrm{pmol}(\mu \mathrm{g} \text { RNA })^{-1]}\right]}\end{array}$} \\
\hline & FS nucleoids & SS nucleoids \\
\hline Isolated nucleoids & 0.012 & 0.040 \\
\hline $\begin{array}{l}\text { Isolated nucleoids preincubated } \\
\text { in transcription assay mixture }\end{array}$ & 0.141 & 0.096 \\
\hline
\end{tabular}

Cell-free protein synthesis. The incorporation of $\left[{ }^{35} \mathrm{~S}\right]$ methionine into TCA-insoluble products reflects de novo protein synthesis programme by exogenous templates. The incorporation was abolished by pretreatment with RNAase or by addition of trypsin after the translation. Omission of leucine and/or tyrosine from the reaction mixture led to a decrease in incorporation of labelled amino acid. SDS-PAGE of the translation products showed that $\left[{ }^{35} \mathrm{~S}\right]$ methionine was incorporated in the presence of nucleoids into several major polypeptides, whereas no observable proteins were synthesized by controls. Although our results are preliminary, a comparison of the proteins synthesized in the presence of $E$. coli $\mathrm{B}$ mRNA and $C$. crescentus SS nucleoid RNA has shown them to be different in number, molecular.weight and relative amounts.

Specific template activity of the nucleoids. Nucleoid-associated mRNAs were quantified by measuring the amount of labelled amino acid incorporated into protein per $\mu \mathrm{g}$ of total RNA present initially. The results indicated that both SS and FS nucleoids contained biologically active mRNAs (Table 3). In some experiments, nucleoids were transferred into the transcription reaction mixtures immediately after isolation. Under the conditions described earlier, RNA synthesis occurred and was monitored by $\left[{ }^{3} \mathrm{H}\right]$ UTP incorporation. The reaction was terminated after $40 \mathrm{~min}$ by chilling to $4{ }^{\circ} \mathrm{C}$. The appropriate samples were then removed from duplicate tubes containing unlabelled UTP and transferred into protein-synthesizing 
assay mixtures. Translation of in vitro and in vivo synthesized mRNAs commenced when the temperature was increased to $37^{\circ} \mathrm{C}$ upon the addition of $\left[{ }^{35} \mathrm{~S}\right]$ methionine. The translational capacity of the nucleoids increased markedly after transcription, indicating that some RNA synthesized in vitro was mRNA (Table 3). The specific activity of FS nucleoids as a template for protein synthesis increased approximately 10-fold after in vitro transcription and was higher than the specific activity of transcribed SS nucleoids.

\section{DIS CUS I O N}

The first part of this study was concerned with comparing in vitro transcription by FS and SS envelope-associated nucleoids of Caulobacter crescentus CB 15. The isolation of nucleoids in high ionic strength buffers (Giorno et al., 1975) stabilizes their structure but is not compatible with RNA synthesis. For this reason nucleoids were isolated in low salt medium in the presence of spermidine (Stonington \& Pettijohn, 1971) and $\mathrm{Mg}^{2+}$. This procedure not only stabilizes the nucleoids but gives optimal conditions for RNA synthesis.

SS and FS nucleoids isolated in this manner are transcriptionally active. They contain endogenous RNA polymerase which can elongate in vitro RNA transcripts initiated in vivo. Experiments with rifampicin, however, indicated that no reinitiation occurred with endogenous polymerase under in vitro conditions. This is almost certainly caused by the loss of the $\sigma$ factor and/or the holoenzyme on isolation. Similar results have been obtained with Bacillus subtilis nucleoids (Guillen et al., 1977).

On addition of $E$. coli RNA polymerase (holoenzyme) to $C$. crescentus nucleoids, transcriptional activity increased 5-fold over the endogenous level. This increased activity was rifampicin-sensitive indicating that reinitiation had occurred. It would have been preferable to use exogenous $C$. crescentus RNA polymerase; however, Amemiya \& Shapiro (1977) have established that the $C$. crescentus and $E$. coli core RNA polymerases and $\sigma$ subunits are functionally analogous, i.e. $C$. crescentus core RNA polymerase can be used in conjunction with $E$. coli $\sigma$ factor to transcribe $E$. coli templates and vice versa.

A very low rate of incorporation of phosphate from $\left[\gamma^{-32} \mathrm{P}\right]$ ATP into RNA transcripts was apparent when compared with that of phosphate from $\left[\alpha^{-32}\right.$ P]UTP. However, the ratio of terminal triphosphate to internucleotide phosphates is very low in RNA, and so these results are not inconsistent with reinitiation occurring as predicted from the experiments with rifampicin.

FS and SS nucleoids were more active templates directing twice the rate of transcription compared with an equivalent weight of purified calf thymus DNA in a low salt assay system. Nucleoid transcription also differed from that of naked DNA in its kinetics and sensitivity to high salt concentrations. This suggests that the tertiary structure of the folded DNA in nucleoids (Swoboda et al., 1982), together with its association with DNA-binding proteins (Haselkorn \& Rouvière-Yaniv, 1976; Rouvière-Yaniv et al., 1979; Lathe et al., 1980), provides a more efficient controlled template for transcription than naked DNA.

Although the rate of RNA synthesis in vitro from both types of nucleoids was similar, the RNA species synthesized differed significantly. The predominant RNA species synthesized by SS envelope-associated nucleoids had a sedimentation coefficient of the same order as rRNA and its precursors, with an additional low concentration of a $3.2 \mathrm{~S}$ species. In contrast, the predominant species obtained from FS nucleoids had a sedimentation coefficient of $3 \cdot 2 \mathrm{~S}$ with no definite peaks in the $16-40 \mathrm{~S}$ region. The nature of this low molecular weight RNA is unknown. It may be tRNA (normally $4 S$ ) or the product of endonucleolytic degradation.

FS and SS envelope-associated nucleoids contained mRNA molecules that were translatable in a cell-free synthesizing system derived from $E$. coli. To detect exogenous nucleoid mRNA translation, it was necessary to convert $E$. coli S30 extract into an mRNAdependent translation system by destroying endogenous $E$. coli mRNA. This was accomplished by using micrococcal nuclease in the same way as described by Pelham \& 
Jackson (1976) for the conversion of reticulocyte lysates into an mRNA-dependent translation system. Treatment with nuclease did not alter the properties of the $E$. coli-derived protein-synthesizing machinery as was demonstrated by correct translation of coliphage MS2, E. coli B RNA and B. licheniformis A5 RNA.

Protein synthesis directed by $C$. crescentus nucleoids appeared to reflect the amount and composition of mRNA species present in the nucleoids at the time of isolation. However, the fidelity of nucleoid mRNA translation remains to be established by immunoprecipitation or enzyme activity tests on individual translation products. Nevertheless, it might be predicted that nucleoids isolated from synchronized $C$. crescentus cells could be a most useful source of stable stage-specific mRNA species.

More than twice as much protein was synthesized in vitro by the FS nucleoids than by SS nucleoids, which could reflect the different amounts of mRNA present in each type of nucleoid at the time of isolation. A sequential in vitro transcription/in vitro translation system was developed to detect any protein synthesis by in vitro-synthesized mRNA. Preincubation of isolated nucleoids in an in vitro transcription mixture for 40 min brought about a dramatic increase in the amount of $\left[{ }^{35} \mathrm{~S}\right]$ methionine incorporated into protein when the nucleoids were subsequently used as a source of mRNA. In the case of the FS nucleoids the increase was more than 10-fold, while for the SS nucleoids it was about 2-fold. These results can most easily be explained if in vitro mRNA synthesis has occurred during the 40 min preincubation, although other explanations involving effects on the control of protein synthesis have not been ruled out. If the FS nucleoid has a high intrinsic capacity to synthesize mRNA in the in vitro transcription assay, this might well explain the high background of RNA species seen between $5 \mathrm{~S}$ and $23 \mathrm{~S}$ which obscures the ribosomal RNA peaks. It remains to be established whether these species are due to in vitro-synthesized mRNA.

\section{REFERENCES}

AMEMIYA, K. \& ShAPIRO, L. (1977). Caulobacter crescentus RNA polymerase. Journal of Biological Chemistry 252, 4157-4165.

Flink, I. \& Pettuohn, D. E. (1975). Polyamines stabilize DNA folds. Nature, London 253, 62-63.

Fuchs, E., Millette, R. L., Zillig, W. \& Walter, G. (1967). Influence of salts on RNA synthesis by DNA-dependent RNA polymerase from Escherichia coli. European Journal of Biochemistry 3, 183-193.

Giorno, R., Stomato, J., Lydersen, B. \& Pettijohn, D. (1975). Transcription in vitro of DNA in isolated bacterial nucleoids. Journal of Molecular Biology 96, 217-237.

Guillen, N., le Hegarat, F., Fleury, A. \& Hirschbein, L. (1977). Folded chromosome of vegetative Bacillus subtilis: composition and properties. Nucleic Acids Research 5, 475-489.

HAGEN, F. \& Young, E. T. (1973). Regulation of synthesis of bacteriophage T7 lysozyme mRNA. Virology 55, 231-241.

HASElKoRn, R. \& RouviÈRe-YANIV, J. (1976). Cyanobacterial DNA binding protein related to Escherichia coli HU. Proceedings of the National Academy of Sciences of the United States of America 73, 1917-1920.

Hirschbein, L., Guillen, N. \& le Hegarat, F. (1976). Isolation and characterization of nucleoids of Bacillus subtilis during growth and sporulation. In Spore Research 1976, vol. 1, pp. 373-390. Edited by A. N. Barker, L. J. Wolf, D. J. Ellar, G. J. Dring \& G. W. Gould. London: Academic Press.
Hopper, J. E., Ko, G. \& Young, E. T. (1975). Comparative analysis of in vivo expression of bacteriophage T7 messenger RNAs during infection of Escherichia coli. Journal of Molecular Biology 94, 539-554.

KIRBY, K. S. (1965). Isolation and characterization of ribosomal ribonucleic acid. Biochemical Journal 96, 266-269.

Lagenaur, C. \& Agabian, N. (1976). Physical characterization of Caulobacter crescentus flagella. Journal of Bacteriology 128, 434-444.

LATHE, R., Buc, H., LecocQ, J. P. \& BANTz, E. K. T. (1980). Prokaryotic histone-like protein interacting with RNA polymerase. Proceedings of the National Academy of Sciences of the United States of America 77, 3548-3552.

LOENING, U. E. (1967). The fractionation of high molecular weight ribonucleic acid by polyacrylamide gel electrophoresis. Biochemical Journal 102, 251-257.

LOENING, U. E. (1969). The determination of the molecular weight of ribonucleic acid by polyacrylamide gel electrophoresis. Biochemical Journal 113, 131-138.

Nikolev, N., Silengo, L. \& Schlessinger, D. (1973). The role of ribonuclease III in processing of ribosomal ribonucleic acid and messenger ribonucleic acid precursors in Escherichia coli. Journal of Biological Chemistry 248, 7967-7969.

Nikolev, N., Schlessinger, D. \& Wellauer, P. K. (1974). 30S pre-ribosomal RNA of Escherichia coli and products of cleavage by ribonuclease III: length 
and molecular weight. Journal of Molecular Biology 86, 741-747.

Pelham, H. R. B. \& Jackson, R. J. (1976). An efficient mRNA-dependent translation system from reticulocyte lysates. European Journal of Biochemistry 67, 247-256.

Pettisonn, D. E. (1976). Procaryotic DNA in nucleoid structure. CRC Critical Reviews in Biochemistry 4, 175-202.

Pettuohn, D. E., Clakkson, K., Kossan, C. R. \& Stonington, O. G. $(1970 a)$. Synthesis of ribosomal RNA on a protein-DNA complex isolated from bacteria: a comparison of ribosomal RNA synthesis in vitro and in vivo. Journal of Molecular Biology 52, 281-300.

Pettijohn, D. E., Stonington, O. G. \& Kossan, C. R. $(1970 b)$. Chain termination of ribosomal RNA synthesis in vitro. Nature, London 228, 235-239.

Rouvière-Yaniv, J., YANIV, N. \& Germand, J. E. (1979). E. coli DNA binding protein HU forms nucleosome-like structure with circular doublestranded DNA. Cell 17, 265-274.
Stonington, O. G. \& Petrijohn, D. E. (1971). The folded genome of Escherichia coli isolated in a protein-DNA-RNA complex. Proceedings of the National Academy of Sciences of the United States of America 68, 6-9.

STUDIER, F. W. (1973). Analysis of bacteriophage T7 early RNAs and proteins on slab gels. Journal of Molecular Biology 79, 237-248.

SwobodA, U. \& Dow, C. S. (1979). Transcription in vitro on isolated Caulobacter nucleoids. Biochemical Society Transactions 7, 1255-1257.

Swoboda, U., Dow, C. S. \& Vitkovik, L. (1982). Nucleoids of Caulobacter crescentus CB15. Journal of General Microbiology 128, 279-289.

Vitkovic, L. \& SADOFF, H. L. (1977). Purification of extracellular protease of Bacillus licheniformis and its inhibition by bacitracin. Journal of Bacteriology 131, 891-896.

ZuBAY, B. (1973). In vitro synthesis of protein in microbial systems. Annual Review of Genetics 7, 267-287. 